\title{
OBITUARIES
}

\section{Sir David Pye, C.B., F.R.S.}

The death of Sir David Pye, on February 22, at the age of seventy-three, at his home in Surrey, caused a deep sense of personal loss to his many friends and colleagues in university and government circles. $\mathrm{He}$ wore his eminence in science and engineering with a modesty and tolerance which engaged the warm affection of those who had the privilege of working with him. He was a scientist engineer who devoted much of his working life to the thermodynamics of the internal combustion engine and its design and construction. His wide knowledge and experience found their expression in "The Internal Combustion Engine", the standard English text-book and work of reference on the subject.

His heart was in university life. Educated at Tonbridge School and Trinity College, Cambridge, he began his career in 1909 as a lecturer in engineering at Oxford, and Fellow of New College, and ended it as Provost of University College, London, in 1951. He faced adverse circumstances and overcame formidable difficulties in both universities.

At Oxford, in the first decade of the century, engineering was fighting for its existence. Pye illuminated the scene in the course of his presidential address in 1952 to the Institution of Mechanical Engineers : ". . . There was one college where, for four years no student ever dared to risk the wrath of the Master, that was known to be impending for anyone who might be so rash as to suggest that he wished to take a degree in engineering science. Then, in 1913, we were astonished to receive a registration from the college in question. Vain jubilation! The wrath from heaven in the shape of the Master of the college, magnificent in full academic robes, was next morning at the doors of the engineering laboratory, demanding that his erring lamb should return to the classical fold. We never saw our potential student again".

One can almost see the quizzical look on Pye's face. He could not have been altogether surprised. Anger never came easily to him, but he must have resolved. then and there to hang on. Throughout his life his invariable courtesy and reasonableness concealed a strong tenacity of purpose. Oxford engineers have good reason to be grateful to him.

The difficulties he faced at University College (the first institution in Great Britain to appoint a professor in engineering) were of an altogether different kind. He became Provost in 1943 of a bombed and dispersed College. It existed more in spirit than in fact, and when the War ended, the problem of satisfying the inultitude of new and returning students called for a miracle. There was no miracle. There was only the cliligent, steady, painstaking day-to-day effort of David Pye, tolerant as ever with those who wanted more than was humanly possible, and stimulating to those who were ready to share the real work. Before his period of office came to an end, the College had more than re-established itself as a great centre of learning and research. His anxieties were at times overwhelming, but his labours must, in the end, have given him a deep satisfaction.

Pye left Oxford in 1914 at the outbreak of war to become an experimental officer in the Royal Flying
Corps. The then professor of engineering at Cambridge, Bertram Hopkinson, soon picked him out, and on demobilization in 1919 he went to Cam. bridge as Fellow of Trinity College and lecturer in engineering. There followed a most fruitful six years of teaching and research on volatile fuels pursued, largely during vacations, in collaboration with the late Sir Henry Tizard and Sir Harry Ricardo at his works at Shoreham.

His career in the Scientific Civil Service began in 1925 as deputy director of scientific research in the Air Ministry at the invitation of Mr. H. E. Wimperis, the first director. Wimperis and Pye laid the founda. tions of a vigorous and lively research department which was to prove its worth in the critical year's ahead. The shadow of war was lengthening when Pye succeeded to the directorship in 1937, and again he faced a period of difficulty and anxiety. Air warfare and air defence loomed large in strategic importance, embracing many fields of science and engineering. New weapons, devices and equipment found their way into the Royal Air Force, and when Pye retired in 1943 he had carried the burden of the day, and what he set out to do was largely accomplished.

Pye disliked damping enthusiasms in others. His imagination gave him a real flair for uncovering other peoples' talents, and much of his life was spent in contriving circumstances favourable to their devolopment. His interests and activities were wide, ranging from enthusiasm for mountaineering and rock climbing, to the love of music and musicians. Many young professionals and amateurs owe much to his warm encouragement.

He married in 1926 the daughter of C. Moore Kennedy, Virginia Frances, who nursed and comforted him throughout the long illness at the end of his life. Our sympathies go out to her, and to her two sons and daughter.

BEN LOCKSPETSER

\section{Prof. B. Gutenberg}

Wiтr the death of Beno Gutenberg on January 25 , seismology loses an outstanding figure. Throughout. an acadomic career of nearly half a century he maintained an astonishingly large output of high-grade papers covering the whole range of seismology, especially in connexion with the propagation of seismic waves through the interior of the Earth. Indeed, it was truly remarked by Prof. Perry Byerly on the occasion of the presentation to Gutenberg of the Bowie Medal of the American Geophysical Union: "It is rare that anyone writes a paper in seismology without referring to him". Of his many achicvement.: perhaps his most celebrated was the calculation in 1912 of the radius of the so-called liquid core of the Earth, usually referred to as the Oldham-Gutenberg core, the existence of which had been inferred by R. D. Oldham in 1906; considering the roughness of the existing data and the tentative methods then available this stands out as a veritable tour de force. and calculations by Jeffreys with a large body of precise data, embodying reflexions from the core that were not known when Gutenberg began his 